\title{
MĂSURI DE ÎNTĂRIRE A CAPACITĂṬII DE ADAPTARE LA SCHIMBĂRILE CLIMATICE A ECOSISTEMELOR ACVATICE
}

\author{
Nadejda Andreev
}

Institutul de Zoologie, e-mail: nadia.andreev@gmail.com

https://doi.org/10.53937/9789975151979.15

\begin{abstract}
Rezumat
În articolul de față se prezintă o sinteză bibliografică privind infrastructurile ecologice și rolul acestora în întărirea capacității de adaptare a ecosistemelor acvatice la efectele nefaste ale schimbărilor climatice (temperaturile ridicate, ploile abundente, secetele). Sunt prezintate diferite tipuri de infrastructuri ecologice: fâșii de păduri, grădini pluviale, pavaj permeabil, șanțuri de scurgere; structuri bioinginerești pentru stabilizarea malurilor. De asemenea, sunt menționate funcțiile pe care le îndeplinesc infrastructurile ecologice pentru menținerea serviciilor ecosistemelor: diminuarea efectelor inundațiilor, stabilizarea malurilor, prevenirea alunecărilor de teren și a eroziunilor cauzate de apă, managementul apelor pluviale, reducerea încărcăturii de poluanți. Pentru implementarea acestor măsuri în bazinul hidrografic al fluviului Nistru sau râului Prut, este necesar un studiu mai detaliat privind starea habitatelor, identificarea zonelor bogate în biodiversitatea acvatică și în special cu specii importante pentru menținerea funcției ecosistemului, zonele cu risc major de inundații sau alunecări de teren.
\end{abstract}

Cuvinte-cheie: infrastructuri ecologice, ecosisteme acvatice, adaptare, schimbare climatică

\section{INTRODUCERE}

Măsurile de utilizare durabilă a resurselor acvatice sunt orientate spre îndeplinirea următoarelor obiective: 1) crearea condițiilor favorabile pentru organismele acvatice și funcționarea ecosistemelor acvatice; 2) menținerea cantității suficiente și calități bune a apei utilizate pentru necesitățile umane. Îndeplinirea acestor obiective devine tot mai dificilă în condițiile modificărilor climatice, cum ar fi intensificarea condițiilor de secetă și temperaturile ridicate sau ploile abundente. Sunt tot mai actuale măsurile care conduc la întărirea capacității de adaptare a ecosistemelor acvatice. În cadrul Strategiei ONU privind apele dulci din măsurile importante de protecție a ecosistemelor acvatice sunt și protecția și instaurarea infrastructurilor ecologice, acestea fiind promovate de Comisia Europeană și ca instrumente cheie pentru conser-

\begin{abstract}
The current article presents a bibliographic overview of green infrastructures and their role in strengthening the adaptive capacity of aquatic ecosystems to the adverse effects of climate change (high temperatures, heavy rains, droughts). Different types of ecological infrastructures are presented: forest buffer strips, rain gardens, permeable pavement, drainage ditches; bioengineering structures for bank stabilization. Also the functions performed by green infrastructures to maintain ecosystem services were presented: mitigating the effects of floods, stabilizing banks, preventing landslides and water caused erosion, stormwater management, reducing the load of pollutants. For the implementation of this approach in the hydrographic basin of Dniester River or the Prut River a more detailed study is necessary on the state of habitats, identification of hotspot areas of aquatic biodiversity, particularly those species important for maintaining of ecosystem functions, highlighting of the areas at high risk of floods or erosion.
\end{abstract}

Keywords: green infrastructures, aquatic ecosystems, adaptation, climate change

varea ecosistemelor în strategia UE privind biodiversitatea până în 2020. Infrastructurile ecologice reprezintă ,o rețea de zone naturale, semi-naturale sau spații verzi, care oferă servicii ecosistemice esențiale care stau la baza bunăstării umane și a calității vieții” [1].

Infrastructurile ecologice amplasate în proximitatea râurilor, au un potențial semnificativ de reducere a vulnerabilității la schimbările climatice și creștere a capacității de adaptare la astfel de modificări. Infrastructurile ecologice contribuie la îmbogățirea circuitului hidrologic natural, reglează fluxul de sedimente prin intărirea malurilor, facilitează procesele de infiltrare și evapotranspirație, precum și contribuie la protecția speciilor sensibile la modificările de temperatură prin oferirea efectului de umbră. Astfel de măsuri contribuie și la îndeplinirea ODD 13 al Agendei Globale 2030, care se axează pe adaptabilitatea și promovarea re- 
zistenței la schimbările climatice și al Strategiei de Adaptare la Schimbările Climatice.

\section{MATERIALE ȘI METODE}

În scopul evaluării stării cunoștințelor privind utilizarea infrastructurilor vierzi pentru protecția ecosistemelor acvatice a fost realizat un studiu bibliografic prin utilizarea instrumentului Internet de căutare al articolelor științifice google.scholar, prin utilizarea cuvintelor cheie „infrastructuri vierzi râu", "infrastructuri vierzi ecosisteme de apă dulce", "structuri de bioretenție râuri”, "structuri bioinginerești protecție râuri”.

\section{REZULTATE ȘI DISCUṬII}

Datele analizate au demonstrat existența mai multor tipuri de infrastructuri ecologice care ar contribui la îmbunătățirea capacității de adaptare la schimbările climatice ale ecosistemelor acvatice:
- fâșii de păduri, care pot acționa în calitate de tampon și habitate pentru fauna acvatică și riverană;

- grădini pluviale, pavaj permeabil, șanțuri de scurgere;

- $\quad$ structuri bioinginerești pentru stabilizarea malurilor (de exemplu garduri vii împletite din salcie, saltele formate din tufărișuri)

Aceste infrastructuri ecologice îndeplinesc un șir de funcții de protecție a ecosistemlor acvatice, prin influențarea vitezei de curgere și diminuarea efectului de inundații, limitarea eroziunii și alunecărilor de teren provocate de apa pluvială, filtrarea și captarea poluanților și a sedimentelor, astfel permițând ca ecosistemele acvatice să aibă o reziliență mai mare la fenomenele climatice nefaste și să fie asigurate condiții mai favorabile de trai pentru organismele acvatice (Tabelul 1). S-a estimat că pădurile riverane pot filtra, asimila, descompune sau stoca în ecosistem peste $80 \%$ din nutrienți și poluanți [3]

Tabelul 1. Funcții importante îndeplinite de structurile ecologice care ar putea mări capacitatea de adaptare a ecosistemelor acvatice la schimbările climatice

\begin{tabular}{|c|l|c|}
\hline N/o & \multicolumn{1}{|c|}{ Funcția îndeplinită de infrastructura ecologică } & Sursa de referință \\
\hline 1. & Reducerea intensității de inundații & {$[4]$} \\
\hline 2. & $\begin{array}{l}\text { Stabilizarea malurilor și prevenirea alunecărilor de teren și a eroziunilor } \\
\text { cauzate de apă }\end{array}$ & {$[5-6]$} \\
\hline 3. & $\begin{array}{l}\text { Managementul apelor pluviale, reducerea încărcăturii de poluanți (de exemplu } \\
\text { cei proveniți din apa pluvială sau apele reziduale) }\end{array}$ & {$[7]$} \\
\hline 4. & Captarea sedimentelor & {$[6]$} \\
\hline
\end{tabular}

În Republica Moldova multe din păduri sau fâșii de protecție riverane au fost defrișate sau utilizate în scop agricol, ignorându-se rolul important al acestora în menținerea rețelei trofice și structurii habitatului acvatic pentru multe specii de nevertebrate și pești. Astfel, habitatele de mal stabile sunt importante pentru supraviețuirea alevinilor multor specii de pești și protecția împotriva $\mathrm{cu}$ rentului, efectului valurilor de căldură, prădătorilor [3]. Diversitatea speciilor, cât și numărul total de organisme bentice este în strictă dependență nu doar de substrtat dar și de suprafața zonelor acoperite cu păduri, care le protejează de efectele negative ale creșterii temperaturii apei [8], aceasta fiind mai ales caracteristic pentru specii sensibile la schimbările de temperatură cum ar fi Plecoptera, Tricoptera, Ephemeroptera [9].
Grădinile pluviale, reprezintă sisteme de biofiltrare, care captează și tratează apa meteorică ce curge de pe acoperișuri și alte suprafețe impermeabile. Aceste tipuri de sisteme pot fi promovate la nivel de gospodărie individuală în localitățile amplasate în proximitatea râului Prut și fluviului Nistru în scop de reducere a impactului influxului de poluanți care vin cu apele pluviale cât și diminuarea efectului inundațiilor.

Grădinile de ploaie pot fi construite și pe trotuare, fiind completate și cu șanțuri de scurgere, denivelări menite a ameliora permeabilitatea terenului și reduce intensitatea apelor pluviale, servind atât ca elemente peizajistice cât și ca grădine de legume [8]. În condițiile de intensificare a secetelor și reducere a cantității de apă acestea ar servi ca sursă de apă asigurând irigarea subterană. 
O altă componentă a infrastructurilor ecologice sunt structurile bioinginerești care presupun utilizarea vegetatiei în combinație cu diverse elemente structurale tehnice (e.g. piatră, ciment, bârne din lemn, sârmă sau membrană geosintentică) penru a întări malurile râurilor și pantele aflate în condiții de degradare prin eroziune sau alunecări de teren cauzate de apele pluviale. Un element potrivit pentru astfel de structuri este salcia, care crește rapid, absoarbe eficient nutrienții și este tolerantă la solurile inundate și lipsă de oxigen în zona rădăcinilor.Nuielile din salcie pot fi modelate ușor pentru forma garduri și structuri vii pentru protecția malurilor (Figura 1).

De asemenea, acestea pot servi ca material pentru producerea diferitor obiecte meșteșugărești locale (de exemplu, coșurile din lozie sau gardurile din nuiele). Având în vedere că salcia este utilizată pe larg și în tratarea apelor reziduale, ar fi probabil important a planta fâșii de protecție a râurilor formate din salcie în zonele cu impact mai mare al apelor reziduale.

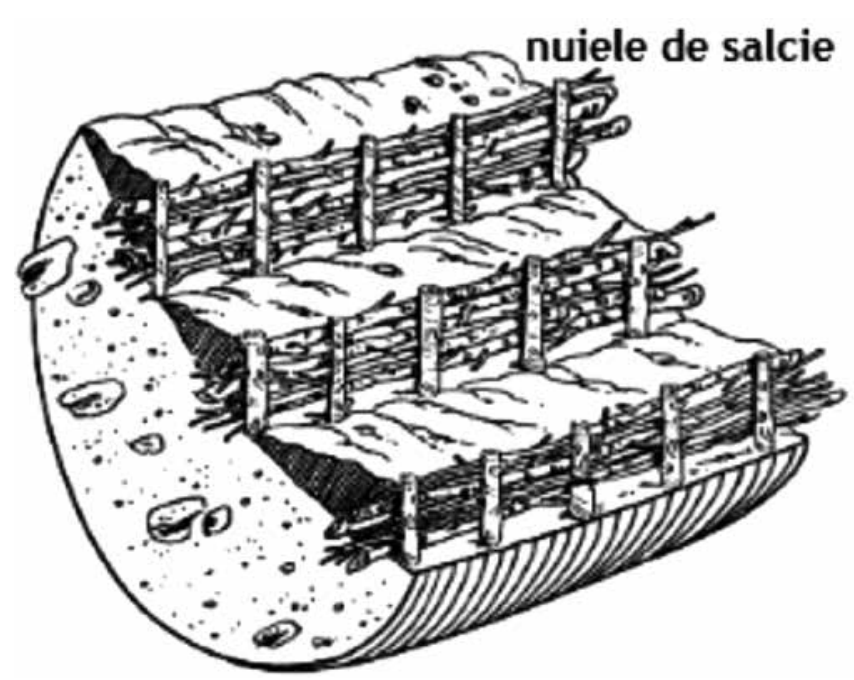

Fig. 1. Structură bioinginerească construită pe pantă cu ajutorul nuielelor din salcie (După Polster, 2008 [10])

Un studiu mai detaliat asupra stării actuale a infrastructurilor ecologice sau potențialul de introducere a unor structuri noi (cum ar fi grădinile pluviale sau structurile bioingineresti de stabilizare a malurilor), cât și al habitatelor de importanță majoră pentru diversitatea acvatică, zonele de risc mare de inundatii sau eroziune a malurilor ar oferi posibilitatea de a realiza unele activități de reconstrucție ecologică.

\section{CONCLUZII}

Infrastructurile ecologice reprezintă o rețea de zone naturale, semi-naturale sau spații verzi, care oferă servicii ecosistemice esențiale. Infrastructurile ecologice din zona râurilor au un potențial semnificativ de reducere a vulnerabilității la schimbările climatice și creștere a capacității de adaptare la astfel de modificări. Aceste infrastructuri ecologice îndeplinesc un șir de funcții de protecție a ecosistemlor acvatice, prin diminuarea efectului de inundații, limitarea eroziunii și alunecărilor de teren provocate de apa pluvială, filtrarea și captarea poluanților și a sedimentelor, ce permite ca ecosistemele acvatice cât și organismelor acvatice să-și întărească capacitatea de adaptare la schimbările climatice, e.g. valurile de căldură, ploile abundente sau seceta îndelungată.

Unele componente de infastructură ecologică (de exemplu, grădinile pluviale, structurile bioinginerești) pot fi promovate prin implicarea populației, aceștia putând fi motivați prin obținerea unui beneficiu direct de asigurare a nutriției sau ca material pentru activități meșteșugărești. Acest domeniu necesită un studiu mai detaliat al stării habitatelor acvatice cât și identificarea zonelor cu risc înalt de inundații sau eroziune din regiunea $r$. Prut și al fluviului Nistru, unde aceste infrastructuri sunt importante.

Investigațiile au fost realizate în cadrul proiectului 20.80009.7007.06 "Determinarea schimbărilor mediului acvatic, evaluarea migrației și impactului poluanților, stabilirea legităților funcționării hidrobiocenozelor și prevenirea consecințelor nefaste asupra ecosistemelor”, finanțat de Agenția Națională pentru Cercetare și Dezvoltare din Republica Moldova și a proiectelor în derulare BSB27 și BSB165 (finanțate de UE în cadrul Programului Operațional Comun Bazinul Mării Negre 2014-2020).

\section{REFERINȚE}

1. Maes, J., Barbos, A., Baranzelli C., Zuliani, G., Batista F., Vadescstele, I., Hiederer, R., Liquete, C., Paracchini, M. L. Mubareka, S., Crisioni, C. J., Castilion C. P., Lavalle, C. More green infrastructure is requred to maintain ecosystem services under current trends in land-use change in Europe.

2. Bolea V., Chira D., Sârbu D. Reconstrucția ecologică, îngrijirea și conducerea ecosistemelor forestiere riverane Perdele Forestiere, 2014 Anul XIX, $N r .34$ 
3. Guo Q., Correa, C. The impact of green infrastructure on flood level reduction for the Raritan River: Modelling assessment. World Environment and Water Resources Congress, 2013

4. Prastica, R. Apriatresnaynto, R., Marthanty, D. Structural and green infrastructure mitigation alternatives present ciliwung river from water-related landslide, International Journal Advanced Science Engineering Information Technology, vol.9, 2019, nr.6, 1825-1832.

5. Evette A., Labonne, S. Rey, F., Liebalt, F., Jancke $O$., Girel, J. History of bioengineering techniques for erosion control in rivers in Western Europe. Environmental Management,; 43, 972-984. 2009

6. Fletcher, T. Vietz, G., Walsh, C. Protection of stream ecosystems from urban stormwater: the multiple benefits of an ecohydrological approach. Progress in Physical Geography, SAGE, 1-13, 2014.
7. Shilla, D., Shilla D. A. Effects of riparian vegetation and bottom substrate on macroinvertebrate communities at selected sites in the Otara Greek, New Zealand, Environmental Sciences, V.9 (3), 2012, 131-150.

8. Turk R. and Kraus H. Bilderback, T. , Hunt W. , Fonteno W. Rain Garden Filter Bed Substrates affect Stormwater nutrient remediation HortScience, HortScience 49(5):645-652. 2014

9. EPA, Global Change research Program, $2008 \mathrm{Cli}-$ mate change effects on stream and river biological indicators: a preliminary analysis, EPA/600/ R07/085

10. Polster, D. Soil bioengineering for land restoration and slope stabilization. Course material for training professional and technical staff. Poster Environmental Services. Accesat la data de 19.11.2020 la https://textarchive.ru/c-2858223-pall.html 